The above theory of the tripartite origin of the Boulder-clays will explain many facts which, at first sight, are calculated to puzzle the observer, and make him think that there is no constant order of succession in the drift-deposits of the north-western plain. The current-distributed subglacial clay could not, everywhere, have been equal in amount. It is indeed reasonable to suppose that in various places, and at various times, there would be a partial or even entire failure in the supply of this clay, so as to leave the sea nothing to deposit but loam, sand, or coarse local grit, which would often contain few or no erratics, as the currents which would bring the clay would likewise be the principal carriers of the floating coast-ice (part of which, however, would appear to have been blown in aberrant directions by wind).

In the lower clay, there is often a change in its character upvards, as if the supply of subglacial clay and erratic stones had been diminishing; in other words, it often becomes less stony, and more intercalated with loam or sand towards its junction with the non-, glacial middle sand. This indeed might be expected on the sup-' position that the lower clay and middle sand were deposited during the same submergence.

The tripartite theory likewise explains the degeneracy of the clays southward from the source of supply; and upward on the hill-slopes where the clays gradually become more earthy and local in their character; for the progress of the submergence must have melted the ice upward, so as to limit its extent and consequent power of supplying subglacial clay. $\quad$ D. Mackintosh.

\title{
COLOURING OF OOLITIC ROCKS.
}

SIR,-An excellent illustration of Professor Judd's remark on the colouration of the Oolites, quoted at p. 480, from "The Geology of England and Wales," may be now seen in a cutting on the Midland Railway to the north of Kettering. The bed is very low down in the Inferior Oolite, doubtless part of the Northampton Sands. It seems to be (I have only noticed it from the train, but I believe it identical with rock I bave elsewhere examined) a soft sandstone, perhaps calcareous. Vertical joints divide its beds into blocks, so that there is a rough resemblance to courses of masonry. Sometimes these blocks are wholly brown; but in other cases the heart of a block is blue-grey, while the exterior for several inches is brown: so that it is evident that the former was the original colour, and that atmospheric water, as may be seen in so many other cases, has converted the pyrite (or, what is here more probable, the carbonate of iron, vide Judd, Geol. Rutland, p. 136) into limonite. The effect produced by this change along the planes of bedding and of jointing is very singular, something like masonry exceedingly coarsely pointed.

T. G. Bonney.

Erratum.-In the Rev. T. G. Bonney's article, Grol. Mag. Nov. 1877, p. 499, lines 8 and 14, for "Hungary," read "Bohemia." 